Mukaddime, 2021, 12(1), s. 45-68.

DOI: 10.19059/mukaddime.781096

\title{
Metinler Arası İlişki Bağlamında Orta Çağ Tarih Yazımında İktibas Yöntemi ve Bilgi Deformasyonu
}

Ahmet KÜTÜK'

Öz

Her dönemin olduğu gibi Orta Çağ tarih yazımının da kendine özgü bir yazım üslubu vardır. Genellikle iktibas ve nakil usulüne dayalı bu üslup, kendinden önceki müelliflerin yazdıklarından ilham alarak yeni eserler vücuda getirmeyi öngörür. Orta Çağ yazarlarının kontrolsüz iktibas alışkanlıkları, benzer tekrarlara sebep olurken tarihsel bilgiyi kendi dönemlerindeki olay, durum veya kişilere uydurma iştiyakları da bilinçli/bilinçsiz bilgi deformasyonlarına sebep olmuştur. Müellifin beğenilme kaygısı, dini, etnik ya da coğrafi aidiyetleri ve içinde bulunduğu dönemin sosyo-politik şartları, bir önceki kaynaktan alınan bilgilerin nasıl servis edileceği noktasında oldukça önemli belirleyicilerdir. Dönemin baskın ideolojisi ya da iktidarı da çoğu zaman aynı olay veya durumların kendi çağına uydurulması noktasında tarihçinin iştahını kabartmıştır. Bu makalede, Orta Çağ tarih yazıcılığının temel karakteri ve dönemin kaynaklarında geçen bilgi tekrarları ele alınacak, bu vesileyle bizzat tarihçi eliyle bilginin özünde meydana getirilen tahrifat örnek metinler üzerinden incelenecektir. Bu çalışmada, özde aynı olan olay, durum ve söylemlerin farklı dönemlerde, farklı coğrafyalarda yazılmış tarihi eserlerde aldığı değişik biçimler örnekler üzerinden irdelenmiş, dönemin tarihçisini bu tür bir bilgi-bozum yönelimine sevk eden sosyal ve psikolojik sebepler üzerinde durulmuştur. Bundan maksat, hangisinin daha doğru/güvenilir olduğunu tespit etmekten ziyade, temel yazım üslubu iktibas üzerine kurulu olan ve önemli ölçüde taklitten beslenen Orta Çağ tarihçisinin bilgiye dokunuşunun özde nasıl bir tahrifata sebep olduğunu göstermeye çalışmaktır.

Anahtar Kelimeler: Orta Çağ Tarih Yazıcılığı, İktibas, Tarihsel Bilgi, Bilgi Deformasyonu.

1 Doç. Dr., Mardin Artuklu Üniversitesi Edebiyat Fakültesi Tarih Bölümü, ahmetkutuk63@gmail.com, ORCID ID: 0000-0002-0092-5447. 


\title{
In the Medieval Historiography the Quotation Method and Informational Deformation in the Context of Intertextual Relationship
}

\begin{abstract}
As in every period, historiography in the medieval times has a specific writing style. This style was generally based on quotation predicts composing new works inspiring from previous authors. This quotation habit of medieval authors causes the stereotype repetition and conscious/unconscious informational de-formation. The main concern of the authors, the socio-political conditions of their period, their religious, ethnic or geographic belonging are important determinants about how to give information from the previous sources. The dominant ideology or power of the period has also whetted the historian's appetite at the point of adapting the same events or situations to his own age. In this article we will discuss the basic character of medieval historiography and the repetitions of information in the sources of the period, and we will analyze the distortion in the essence of the knowledge by the historian himself will be examined through sample texts. In this study, the different forms of events, situations and discourses that are originally the same in historical works written in different periods and in different geographies are examined through examples, and the social and psychological reasons that led the historian of the period to such a knowledge-distortion orientation are emphasized. The purpose of this is to try to show what kind of a distortion in essence the medieval historian's touch of knowledge, whose basic writing style is based on quotation and who feeds on imitation, rather than determining which one is more accurate/reliable.

Keywords: Medieval Historiography, Quotation, Historical Information, Informational Deformation.
\end{abstract}

\section{Extended Abstract}

In the historical process, each era has had a distinctive writing style. The authors of the period have an indisputable role in the formation of this style. First of all, the historians' records are fed by the political and social conditions of his time. For this reason, the historian of every period often desires to adapt the information he receives from the past to his own age. Thus, the gaps encountered in the information obtained from the previous ones are filled in the scale of the requirements and socio-political atmosphere of the age and this orientation accelerates the change/deformation process of historical knowledge. According to Ibn Haldun, who claims that the historian is a part of the deformation of knowledge, the authors' habit of writing as transmitter, imitator and uncritical caused different interpretation of events and situations and an increase in information distortion. One of the main reasons that pushes a medieval historian to write a historical work is often to show the ability of eloquence and to gain material-moral benefit on this occasion. Many authors have seen the writing of a historical work as a tool to show their 
literary talents, so the activity of writing history has generally turned into a show of force that the author performs through the person to whom he dedicated his work. Since the written works were dedicated to the sultans and their families, as well as to the high-level bureaucrats such as viziers and commanders, they often had an ornate and eloquent content. Thus, writing history was seen as an important tool for the author to reveal his own ability, and a narrative, in which formal beauty comes to the fore rather than content, has become dominant in these works. When the issue is evaluated methodologically, it can be said that one of the most prominent features of medieval historiography is the method of quoting. This method, which anticipates to make direct quotations from the works of previous historians, has resulted in the repetition of various narratives, which are quite similar in content, by adapting them to the era. Medieval historians who seeing the works of those before them and quoting them, rarely mentioned the name of the author or work from which they obtained the information, often presented the information to the reader as a set of information they had discovered. Moreover, these authors have consciously or unconsciously become a part of the distortion of information, with their interventions to the essence of information with various concerns. Especially, in works attributed to a dynasty and its entourage (Saldjuknâmeh, Tawarikh-i Âl-i Osman, etc.) or by representatives of a community or group (religious leaders, members of the sect, officials, etc.), such deformations can be seen more clearly. The reasons leading the medieval scribe to such an orientation are various. The most important of these is the effort to gain legitimacy and holiness for his own age. Also, the author's closeness to the management and his effort to benefit, his material and moral benefits, his prospects from the social environment he is in, the writer's own political, sectarian, religious or ethnic affiliations were effective in this deformation. Apart from giving legality to a dynasty and attributing holiness to it, the habit of adapting stories that are fed from verbal memory to time and situation, with the concern of making his works interesting, explains the reason why such repetitions appear with different subjects in many sources by becoming a "topos". The main reason for the anachronism, logical mistakes and routine repeats that historians drag into is due to these habits that they cannot restrain. In this study, the different forms of events, situations and discourses that are originally the same in historical works written in different periods and in different geographies are examined through examples, and the social and psychological reasons that led the historian of the period to such a knowledge-distortion orientation are emphasized. The purpose of this is to try to show what kind of a distortion in essence the medieval historian's touch of knowledge, whose basic writing style is based on quotation and who feeds on imitation, rather than determining which one is more accurate/reliable. In addition, the conclusion to be drawn from all of these is not that everything written in the sources is made up, but how important it is to use the information given after it is placed in a comparative and logical context. 


\section{Giriş}

Bilgi, üzerinden zaman geçtikçe kırılganlaşır, değişir ya da değiştirilir. Bilginin tahrif edilmesinde ya da daha doğru bir ifadeyle çağa uydurulmasında o dönemin tarihçilerinin etkisi tartışılmazdır. Ibn Haldun (ö. 1406), (I, 2007: 194) meşhur eseri Mukaddime'de tarihçinin nakilci, taklitçi ve tenkitsiz yazma alışkanlığının, ahval ve ananeleri farklı yorumlamasına sebep olduğuna dikkat çekerek onun bu tür tahrifatın önemli bir parçası olduğunu vurgulamaktadır. Tarihçinin yazdıkları aynı zamanda kendi döneminin siyasi ve toplumsal şartlarından beslenmektedir. Her tarihçinin kendi yaşadığı dönem ve toplumun bir ürünü olduğunu dile getiren çağdaş yazar E. Hallet Carr, (2002: 42, 49) tarihçi ile yaşadığı çağ arasındaki bu doğrusal ilişkiye dikkat çekmek için şöyle demektedir: "Bir tarih eserini ele aldığınızda, baş sayfadaki yazarın adına bakmak yeterli değildir. Yayın ya da yazım tarihine de bakın. Bu, kimi zaman çok daha açıklayıcı olur. (...) Öyleyse, tarihçi de bir bireydir. Öteki bireyler gibi o da aynı zamanda bir toplumsal olaydır, ait olduğu toplumun hem ürünü hem de isteyerek ya da istemeyerek sözcüsüdür”. Carr'ın, günümüz tarihçilerini betimlemek için kullandığı bu ifadeleri tüm tarih yazarlarına genellemek mümkündür. Hangi dönemde yaşamış olursa olsun birçok tarihçi, öncekilerden elde ettiği verilerde karşılaştığı boşlukları yaşadığı çağın gerekleri ve sosyo-politik havası ölçeğinde doldurma eğilimi içindedir ve bu psikolojik yönelim tarihsel bilginin değişim/deformasyon sürecini hızlandırır. Tarihçinin bu iştiyakı, zamandan geriye doğru gittikçe daha belirginleşir. Özellikle monarşik rejimlerde tarihçinin (müverrih/müellif) iktidar ile olan münasebetleri ve yaşanmışlıkları, neyin nasıl anlatılacağı noktasında belirleyici unsurlar olmuştur.

Meseleyi Orta Çağ tarih yazarı ve yazım üslubu özeline indirgeyecek olursak iktibas (alıntılama), benzer tekrarlar ve tahrifatın bu dönem tarih yazım üslubunda daha baskın olduğu söylenebilir. Bu dönem müelliflerinin, bir hanedanın güçlü olduğu dönemde onları yüceltme gayreti çerçevesinde olmamış hadiseleri uydurma ihtimalleri, tarihçinin yazım amacı göz önüne alındığında akla uzak bir ihtimal değildir. Bu tür kayıtların güvenirliğini tartışan R. P. Lindner'a göre "[Orta Çağ'da] sarayda görev yapan bir kronik yazarı olmak aynı zamanda bir kâtip olmak demekti elbette" (Kafadar, 2010: 152). Böylece gayrı ihtiyari olarak yaşadığı çağın ve ortamın bir parçası haline gelen müellif, çoğu zaman eserini ithaf ettiği mecranın (hanedan, sultan, vezir, komutan vs.) cazibesine kapılır, onun varlığına meşruiyet kazandırmak için önceki dönemlere, devletlere veya sultanlara ait hikâye veya olayları onlara uyarlamaktan çekinmez. Bu vesileyle başarılar ve başarılı iktidarlar çoğu zaman bu müelliflerin kaleminde yarı efsanevî hikâyelerle yüceltilir, sevilen ve sempatik isimler bir anda aslında hiç yaşamadıkları olayların kahramanı olup çıkarlar.

Bu noktada, "bu dönem tarihçisi önceki kaynaklardan aldığı bilgiyi neden değiştirme/bozma ihtiyacı duyar?" sorusu önem kazanmaktadır. Bu sorunun cevabı muhteliftir. Bilgiyi işleyen müellifin yaşadığı çevre, mekânsal, mezhepsel, 
dinî ve etnik aidiyetleri çoğu zaman değişimin başat sebebi olur. Ayrıca iktidara yakınlık ve yaranma çabası, kendi çağına meşruiyet kazandırma ülküsü, maddi ve manevi nüfuz elde etme gayreti gibi âmiller bu deformasyonda etken olabilir. Tarihçilerin sık sık içine sürüklendikleri anakronizm, mantık yanlışları ve kalıplaşmış tekrarların (topos) temel sebebi, onların dizginleyemediği bu alışkanlıklarından kaynaklanmaktadır. Bu çalışmada; özde aynı olan olay, durum ve söylemlerin farklı dönemlerde, farklı coğrafyalarda yazılmış tarihi eserlerde aldığı değişik biçimler muhtelif örnekler üzerinden irdelenecek, dönemin tarihçisini bu tür bir bilgi-bozum yönelimine sevk eden sosyal ve psikolojik sebepler sorgulanacaktır. Ancak bu örneklere geçmeden evvel Orta Çağ tarih yazarlarının yazım biçimi ve çalışma yöntemi hakkında tespitler yapmak gerekir.

\section{Orta Çağ Müellifinin Yazım Üslubu ve Çalışma Yöntemi}

Bir Orta Çağ müellifinin çalışma yöntemini tespit etmek istiyorsak "bu dönemde neden tarih yazılır?” sorusuna cevap arayarak başlamamız gerekir. Çünkü bir müellifin yazma amacını ortaya koymadan yazma üslubunu tahlil etmek anlamsızdır. Bu soruya ilk olarak "geçmişte yaşamış kavimlerin yaptıkları ve yaşadıklarından ders çıkarmak” şeklinde bir cevap verilebilir. Bu cevap, uzak hedef olarak tarih yazım amacının dayandığı en temel dinamik olsa da tek başına konuyu izah etmeyecektir. Geçmişteki hadiseleri anlayıp bunlardan an ve istikbale yönelik sonuçlar çıkarmak sadece Orta Çağa özgü değil -günümüz de dâhil- her devir için söz konusudur ve bu hedef zaten tarih anlatısının odağına yerleşir. Ancak bir Orta Çağ müellifi için tarih yazma amacının bundan daha fazlası olduğu kesindir. Onun zihninde tarihsel materyal, çoğu zaman birbirine bağlı iki ana hedef için uygun bir araç olarak görülmüştür. Birincisi belagat yeteneğini ispatlamak ve bu yolla gözle görülür bir itibara kavuşmak, ikincisi bu takdir edilmiş belagat yöntemi aracılığıyla maddi ve manevi çıkarlar elde etmek. Dolayısıyla Orta Çağ müelliflerinin zihin dünyasında "yaranma" yani makam mevki elde etme ve "nemalanma" yani maddi çıkar elde etmenin en geçerli yollarından biri hanedanlara veya onların başındaki sultanlara ithaf edilen tarih içerikli süslü eserler yazmak olmuştur. Tarih yazmak, müellif için aynı zamanda kendi yeteneğini ortaya koymanın en önemli aracı olduğu için bu eserlerde içerikten ziyade biçimsel güzelliğin ön plana çıktığı bir anlatı kendini gösterir. Bu çalışma yöntemi ise çoğu zaman bilgi tekrarlarına, taklitlere ve hatta bilgi tahrifatına sebep olmuştur. Bu konuya çokça vurgu yapan ibn Haldun'a göre (I, 2007: 194) hanedan ve sultanlar için tarih yazmayı alışkanlık haline getirmiş olan bu dönemin tarihçisi önemli ölçüde taklitten beslenir ve sorunun esas kaynağı da onun bu alışkanlığıdır. Onun şu cümleleri meseleyi en iyi şekilde özetlemektedir:

İslam'daki büyük tarihçiler, eski çağlara ait haberleri geniş ölçüde derleyip topladılar. Bu haberleri kitapların sayfalarına yazarak eserlere tevdi etmiş oldular. Fakat asalak tarihçiler bu haberleri sahte ve uydurma olanlarla karıştırdılar. Bu hususta vehme kapıldılar veya haber uydurdular. Süsledikleri zayıf rivayetleri birbirine katıp karıştırdılar ve ortaya koydular. Onlardan sonra gelenlerin çoğu bu eserlere tabi 
oldular ve onları takip ettiler; bu gibi rivayetleri nasıl işittilerse bize o şekilde naklettiler. Vakaların ve ahvalin sebeplerini mülahaza etmediler, bu hususa riayet etmediler. Saçma rivayetleri terk ve reddetmediler. İmdi (onlarda) tahkik azdır, ayıklama ciheti ekseriya cılızdır, hata ve vehim haberlerin soydaşıdır, hemen onlara bulaşır. İnsanoğlundaki taklid köklü ve irsîdir (ibn Haldun, 2007: 158).

Durum genel olarak bu şekilde görünse de bütün Orta Çağ müellifleri ve eserleri için aynı şey iddia etmek doğru değildir. Erken dönem İslam tarihçileri arasında nakilci ve taklitçi zihniyetle yazılmış olsa da eserleri hanedan veya sultana ithaf edilmemiş, "tarih için tarih" düşüncesiyle vücuda getirilmiş vekayinâmeler elbette vardır ve bu eserlerde tahrifat yukarıda bahsedilenlere kıyasla daha azdır. Şu bir gerçek ki müelliflerin hanedan ve çevresindekilere atfettiği eserlerde (Selçuknâme, Tevarih-i Âl-i Osman vs.) veya Orta Çağ’da çok yaygın olarak görülen bir cemaat ya da grubun mümessilleri tarafından (din adamları, mezhep mensupları, resmi görevliler vs.) kaleme alınan eserlerde bu tür tahrifat daha bariz bir şekilde seçilebilmektedir.

Tahrifata sebep olan yönelimlerden biri de süslü ve beliğ yazma iștiyakıdır. İslam müellifleri arasında belagat merkezli tarih yazma konusunda Firdevsîyi (ö. 1020 ?) ve onun kaleme aldığı Şehnâme adlı eserini bir kırılma noktası olarak kabul etmek gerekir. Bu müellifin başını çektiği süslü, şiirsel ve estetik tarih yazma geleneği, uzun asırlar boyunca Orta Çağ tarihçileri için vazgeçilmez bir model teşkil etmiş ve bu üslup tarih yazımının ana karakterini biçimlendirmiştir. Firdevsî’nin eserini kaleme alma hikâyesinde dahi onun yukarıda belirtilen amaçlara matuf yazdığı görülmektedir. Anlatıldığına göre Firdevsî, eserini binbir güçlükle tamamladığında dönemin muktedir hükümdarı Gazneli Mahmud’a (9981030) sunmuş, ancak beklediği takdir ve maddi karşılığı alamadığı için bu kez onu hicveden bir şiir kaleme almıştır (Kanar, 1996: 126). Bu örnek, bu dönemde tarih yazma faaliyetinin tek başına "geçmişteki olayları aydınlığa kavuşturmak" amacına matuf olmadığını göstermektedir. Maddi çıkarlar elde etme dışında "edebi kaygı" veya halk ve hükümdarlar nezdinde "tescil edilmiş bir itibar arayışı” gibi etkenler, Orta Çağ müelliflerini tarih yazmaya sevk eden önemli bir itici güç olmuştur. Firdevsîyi müteakip birçok tarih yazarı, bir tarih eseri kaleme almayı edebi yeteneklerini göstermek için bir araç olarak görmüş, böylece tarih yazma faaliyeti, çoğu zaman müellifin eserini ithaf ettiği kişi üzerinden gerçekleştirdiği bir gövde gösterisine dönüşmüştür.

\section{Orta Çağ Tarih Yazımında İktibas Yöntemi ve Temel Karakteri}

Müelliflerin önemli ölçüde üsluptan esinlenen çalışma yöntemleri, Orta Çağ tarih yazıcılığının temel karakterinin iktibas ve tekrar üzerine kurulu bir esasa dayanmasına sebep olmuştur. Dönemin tarihçileri, önceki eserlerden kendi eserlerine yazım üslubu dışında azımsanmayacak miktarda bir veri akışı da gerçekleştirmişlerdir. Böylece iktibas yöntemi, onlara eserlerinin ana harcını oluşturacak materyali kolayca sağlamıştır. Esasen iktibas, sadece Müslüman 
yazarların değil, tüm Orta Çağ boyunca Süryani ve Ermeni kilise tarihçilerinin de sık sık başvurduğu bir yöntem olmuştur. Dahası orijinal nüshaları kaybolmuş bazı Süryani vekayinâmeler bile kendilerinden istifade etmiş müteakip tarihçilerin, "bilgiyi olduğu gibi dercetme" alışkanlıkları vesilesiyle günümüze ulaşabilmiştir. ${ }^{2}$ Kaybolmuş bir eserin içeriğinin günümüze intikalini sağlama noktasında bu nevi olumlu çıktıları olmakla birlikte bu alışkanlık, müellifin iktibasla yetinmeyip alıntıladığı bilginin üzerinde bilinçli veya bilinçsiz değişiklikler yapması sebebiyle çoğu zaman deformasyonla sonuçlanmıştır. Bu şekilde kendilerinden öncekilerin eserlerini görerek onlardan alıntılar yapan Orta Çağ tarihçisi; bilgileri alıntıladıkları müellif ya da eserin adını nadiren anmış, verilen bilgileri, okuyucuya çoğu zaman kendi keşfettiği bir bilgi kümesi gibi takdim etmiştir. Kendi yazmadığı bir metni kısmen veya tamamen eserine dercederek kendisine aitmiş gibi göstermek günümüz şartlarında bariz bir ahlakî problem olarak kabul edilse de Orta Çağ yazım metodunun temel karakterinin bu alışkanlıktan beslendiği bilinciyle meseleyi o dönemin şartları içinde değerlendirmek gerekir.

Orta Çağ tarih yazımının, referanssız iktibastan daha önemli görülmesi gereken yapısal bir problemi daha mevcuttur: Doğrudan alıntılanan bilgilerin zamanın şartları ve duruma göre değiştirilmesi, dönüştürülmesi yani özünün önemli ölçüde tahrif edilmesi. Aslında Orta Çağ yazarlarının önceki kaynaklardan aldıkları materyali, bir tür bilgi-bozum sürecinden geçirerek kendi dönemlerine uyarlama yönelimlerinin sebebi açıtır. Her şeyden evvel, onlar maddi veya manevi bir çıkar elde etmek istiyorlarsa eserlerini ilginç ve okunur kılmak zorundaydı. Bu şekilde estetik amaçlara matuf yazılan bir eserde doğal olarak beğenilme kaygısı ön plandaydı ve olayların kuru kuruya aktarıldığı bir anlatı ile bunun sağlanamayacağı açıktı. Bu noktada kendilerinden öncekilerin kaydettiği efsanelerle yoğrulmuş ilginç hadiseler Orta Çağ tarihçileri için önemli bir ganimet olmuştur. Böylece müellifler öncekilerden aldıkları bilgileri bilerek ya da bilmeyerek (aslında çoğu zaman bilinçli bir şekilde) kendi dönemleri ve durumlarına uydurarak deforme etmişlerdir. Aşağıda, farklı dönemlerde kaleme alınmış kaynaklarda tespit edilen benzer içerikli pasajlar, metinler arası ilişki bağlamında irdelendiğinde bu bilgi-bozumun boyutları daha açık bir şekilde ortaya çıkmaktadır.

\section{Aynı Olaylar, Değișik Tarihler, Farklı Özneler}

Yukarıda söylediklerimizi örnek metinler üzerinden vermeden önce müelliflerin bilginin orijininde bariz değişimler icra etmelerinin sebepleri üzerinde bazı önermelerde bulunmak istiyoruz. Şayet bu deformasyon sehven ya da dikkatsizlikle icra edilmişse bu konuda söylenecek bir şey yoktur. Ancak kasten yapılmışsa müellifin yukarıda bahsedilen dinî veya etnik aidiyetleri, iktidara

\footnotetext{
${ }^{2}$ Mesela, Mar Yeşua Kroniği olarak bilenen Süryani kroniği bu vesileyle günümüze ulaşmıştır (Bu konuda bkz. Duygu, 2019: 50-52).
} 
yakınlığı, eseri ilginç kılma kaygısı gibi etkenlerden söz edilebilir. İktidardan nemalanan bir müellif için bu bozmaların daha makul bir sebebi vardır: Meșruiyet kazandırma ve kutsallık atfetme. Orta Çağ vekayinâmelerinde boy gösteren öznesi değiştirilmiş birçok yarı efsanevî hadise bu amacı güden müellifler eliyle zamana uydurulmuştur. Bu noktada ilk ve en yaygın anlatılardan biri olarak birçok Orta Çağ İslam tarihçisinin başvurduğu bir efsane "göğsünden ay çıkması ve bütün dünyayı gölgelemesi" hadisesini ele alalım. Daha ziyade Osmanlı Devleti'nin kuruluşu vesilesiyle okuduğumuz bu anekdot Aşıkpaşazâde'nin (ö. 1484'ten sonra) tarihinde şöyle verilir:

[...] Osman Gazi uyuyunca düşünde bu yüce kişinin koynundan bir ayın doğarak geldiğini ve kendi koynuna girdiğini gördü. Bu ay Osman Gazi'nin koynuna girdiği anda göbeğinden bir ağaç biter, gölgesi bütün âlemi kaplar ve gölgesinin altında dağlar meydana gelir ve bu dağların dibinden sular çıkar. Bu çıkan sulardan kimileri içer, kimileri de bahçeler sular ve çeşmeler akıtır. Sonra [Osman] uykudan uyandı, gelip Şeyh'e [Edebalı] haber verdi. Şeyh, 'Oğul Osman Gazi, sana müjdeler olsun, yüce Tanrı sana ve nesline padişahlık verdi, kutlu olsun. Ayrıca benim kızım Malhun, senin eşin olacak' dedi ve o anda nikâhlayıp kızını Osman Gazi'ye verdi (Âşık Paşazade, 2003: 5758; Köprülü, 1991: 6; İnalcık, 200ob: 131-132; Giese, 2000: 153-154).

İlk olarak şunu belirtelim ki bu hikâye içerisine serpiştirilmiş mistik öğeler, anlatının önemli ölçüde sözlü gelenek ve menakıpnâmelerden beslendiğine işaret etmektedir (İnalcık, 2000a: 97, 101; Imber, 2000: 247). Zaten müellifin kendisi de eserinin, I. Beyazıd (1389-1403) zamanına kadarki kısmını bir müddet evinde misafir olduğu Yahşı Fâkih'in yazmış olduğu ve kendisine armağan ettiği Menâkıb- Âl-i Osman adlı eserinden istifade ile oluşturduğunu açıkça belirtir (Âşık Paşazade, 2003: 51; Oruç Beğ, 2008: 9; İnalcık, 200ob: 121, 127; Kafadar, 2010: 148; Özcan, 1991: 7). Aşıkpaşazâde'nin Osman Bey’i özne yaparak aktardığı bu olay, aynı dönemde ve sonraki asırlarda yaşamış Osmanlı tarihçilerinin elinde farklı detaylarla anlatılmaya devam etmiştir. Nitekim Aşıkpaşazâde ile aşağı yukarı aynı dönemde yaşadığı bilinen Anonim bir Tevarih-i Al-i Osman'da bu rüyayı Osman'ın değil babası Ertuğrul'un gördüğü söylenir (Anonim, 1992: 10). Hikâye, sonraki asrın Osmanlı tarihçileri tarafından da büyük bir iştahla kullanılmıştır. Rüya motifinin Neşrî’nin (ö. 1520 ?) eserinde aldığı biçim şöyledir:

[... ] Bazen Osman, onun [Edebali] zaviyesinde misafir olurdu. Bir gece rüyasında görür ki Şeyhin koynundan bir ay çıkıp gelip kendi koynuna girer. $O$ anda göbeğinden bir ağaç bitip âlemi kaplar gölgesinde dağlar var, o dağların dibinden pınarlar çıkıp akar. Kimi bağları sular kimi çeşmeler akıtır. Ertesi gün Osman rüyasını o azize [Edebali] aktarır. Seyh 'Ya Osman! Müjdeler olsun. Sana ve evladına Hak Teâla saltanat verdi. Bütün âlem çocuklarının himayesinde olsun. Ve benim kızım Malhun sana helal olsun' diyerek kızını onunla evlendirdi (Neşrî, 2008: 40-41; Gibbons, 1998: 20). ${ }^{3}$

Aşıkpaşazâde ile Neşrî'nin metinleri karşılaştırıldığında birbirinin neredeyse aynısı olduğu görülmektedir. Dönemin iktibasçı yazım geleneği, Neşrî ve ardıllarının Aşıkpaşazâde'yi ana mehaz olarak görmesini ve onun eserinde yer alan bilgileri hafif dokunuşlarla kendi eserine aktarmasını gerektirmiştir (Özcan,

3 Kitapta Osmanlı Türkçesine ait kelimelerin günümüz Türkçesindeki karşılıkları kullanılmıştır. 
1991: 7). Neşrî'den yaklaşık yarım asır sonra eserini kaleme almış olan Hoca Sadeddin (ö. 1599) de Osmanlı'nın kuruluşu kısmında bu meşruiyet kazandırıcı efsaneyi kullanmayı ihmal etmemiştir:

$[\cdots]$

[Osman] Hem yalvardı yakardı hem secdeye vardı/ Açık gözleri, doldu uykuyla kapandı.

Gördü ki ufuktan bir dolunay doğmakta/ Durağı yüce şeyhin makamı olmakta, Gelince durdu Osman'ın karnı üstünde/ Dallı budaklı bir ağaç bitti özünde, Öyle bir dal ki Tanrı'nın sanki gölgesi/ Bittiği yer ise Osman'ın temiz göbeği, Bir ağaç ki mutluluk onda boy vermiş/ Kökleri oynatılmaz yerden öyle bitmiş Büyümüş, yükselmiş gölgesi ta göklere/ Yapraklarının gölgesi düşmüş illere Gölgeliğinden tepeler yer almış/ Her dağ eteğinde temiz pınarlar akmış Bu pınarlara kol kol insanlar gitmekte / Kimi buradan bostanlara su vermekte Kimi bunları âbı-ı hayat gibi içer/Kimi bağında bahçesinde ekin biçer Kimi bunlarla çeşmeler hayırlar yapar/ kimi bu çayırlarda safâlara dalar Açıldı gözü de bahtı gibi uykudan/yorduğu düşü öğrendi Edebalı'dan Şeyh dedi Ey talihi bahtı parlak civan/ Sen çoluğunla çocuğunla oldun Hakan Muştular sana ki bundan böyle Han oldun/ Tuğ ve sancak çeri sahibi sultan oldun Bu düş oldu bana güveyliğine berat/ diyerek onla eyledi bunu nasihat

[... ] (Hoca Sadeddin, I, 1974: 28-29).

Sadeddin'in bu şekilde aktardığı hikâyenin önceki iki müelliften tek farkı, nazım biçiminde yani şiirsel bir dille aktarılmış olmasıdır. Hemen belirtelim ki hikâye, aynı şiirsel anlatı biçimiyle Sadeddin'den önce yaşamış II. Beyazıd dönemi tarihçilerinden Kemal adlı bir müellifin Selatin-nâme adını verdiği eserinde de geçmektedir (Krş. Selâtin-nâme, 2001: 35-36). Bu biçim farkı dışında her ikisinde de anlatı; Aşıkpaşazâde, Neşrî ve diğerlerinin aktardığı gibi Edebalı'nın rüyayı hayra yorması ve kızını onunla evlendirmesiyle mutlu sonla bitiyor.

Buraya kadar verilenler, Osmanlı tarih müelliflerinin aynı hadiseyi birbirlerinden ufak farklılıklarla aktardıklarını ve bu durumun da gayet doğal olduğunu düşündürebilir. Ancak aynı efsanevî hikâyeyi, Osmanlı'dan birkaç asır önce yazılmış vekayinâmelerde aradığımızda karşılaştığımız sonuç ilginçtir. Yukarıda Osman/Ertuğrul için anlatılan rüya görme motifi, 12.-14. asır müelliflerinin kaleminde kendi dönemlerinin farklı kişi ve devletleri için de kullanılmıştır. Bunlardan birisi, olayın Gazneli Devleti'ne uyarlanmış şeklini aktaran Cüzcanî (ö. 1266'dan sonra)'dir. Tabakât-ı Nasırî adını verdiği eserinde bu müellif Gazneliler ve Gazneli Mahmud için oldukça benzeşen bir hikâye anlatır ve özü şöyledir:

[... ] Onun [Gazneli Mahmud] doğumundan evvel [babası Sebüktegin] rüyasında evinin ortasındaki ocaktan bir ağacın çıktığını gördü. Ağaç büyüdükçe bütün cihan onun 
gölgesi altında kaldı. Bu rüyanın etkisiyle uyanınca tabiri ne olabilir diye düşündü. Bir rüya tabircisi geldi ve Hak Teala'nın ona bir oğul verdiğini müjdeledi. Sebüktegin sevindi ve ‘bu oğula Mahmud adını koydum' dedi (Cüzcanî, 2015: 30; Köprülü, 1991: 7).

Hikâyenin başka bir versiyonu da diğer bir Orta Çağ müellifi Hüseynî’nin (ö. 1194'ten sonra) Ahbaru Devleti's Selçukiyye adlı eserinde Selçukluların kurucusu Selçuk Bey için anlatılır. Buradaki sürüm, "bir ağacın göğermesi ve cihanı gölgelemesi" şeklinde değilse de rüya görme, bu rüyayı bir bilgeye yorumlatma ve neticede soyundan bir devletin çıkacağı ve cihana hâkim olacağı gibi estetik motifler oldukça benzeşir. Hikâye şöyledir:

[...] Emir Selçuk yüz sene yaşadı. Bir gece rüyasında ateşe işediğini ve bu ateşin kıvılcımlarının arzın doğu ve batı taraflarına doğru sıçradığını gördü. Bunun üzerine bir muabbire [rüya yorumlayan] müracaat etti. Muabbir 'senin neslinden arzın en uzak köşelerine temellük edecek melikler doğacak' dedi (Hüseyni, 1999: 2; Ahmed b. Mahmud, I, 1977: 5; Divitçioğlu, 2015: 80).

Görüldüğü gibi hikâyenin üç ayrı devlet için anlatılan versiyonunda detaylar farklı olsa da ana olay, yani bir rüya görülmesi ve bunun rüyayı gören kişinin neslinden çıkacak cihangir bir devlete yorulması gibi unsurlar aynıdır ve bu hikâye sonraki asırlarda Osmanlı müelliflerinin kaleminde Osman Gazi'ye uyarlanmıştır. Erken Osmanlı dönemi tarihlerinin (Tevarih-i Âl-i Osman) menakıpnâme ve gazavatnâmelerden beslenerek yazıldığını da hatırlayacak olursak (İnalcık, 2000a: 100; Kafadar, 2010: 151) bu tür bir hikâyenin bu dönem müellifleri için eşsiz bir malzeme olarak görülmesinin sebebi kolayca anlaşılır.

Eserlerdeki ana ögeler karşılaştırıldığında bu kehanetli rüya hikayesinin, hanedanların kökeni ve meşrulaştırılması hususunda Orta Çağ edebi anlatısında yaygın olarak kullanılan topos’lar olduğu görülmektedir (Inalcık, 200ob: 132) ve C. Kafadar'ın belirttiği üzere (2010: 151) bunlar 15. yüzyıldaki ideolojik gelişmelerin seyri göz önünde bulundurulmak suretiyle okunmalıdır. Ona göre bu nevi öyküler, aslında hiçbir zaman gazi olmayan erken Osmanlı dönemi hükümdarlarını gazi sıfatıyla yüceltmek için 15. yüzyıl sonlarından itibaren yazılmaya başlanan "ısmarlanmış saray tarihlerinin" bir neticesidir (Kafadar, 2010: 153). Aslında hikâyenin, Osmanlı tarihçileri tarafından anlatılan sürümleri de dâhil bu tür yarı efsanevî motifler içermesi önemli ölçüde sözlü bellekten beslenmiş olduğuna işaret etmektedir ki bu vesileyle aynı anlatıya Oğuz Kağan Destanı'nda rastlamak bizleri şaşırtmamalıdır. Hikâyenin Reşidüddin Oğuznâmesi'ndeki şekli şöyledir:

[... ] Onların içinde Keraküçi Hoca'nın oğlu Toqsurmuş içi adında çadır iskeleti işleyen bir usta ve üç oğlu vardı. [... ] Bu zat gece rüyasında göbeğinden sağlam gövdeli ve pek çok dal budaklı üç ağaç çıktığını gördü. Bunların tepesi göğe ulaşıyordu. 'asılları yerde dalları gökte'. Rüyasını anlattığı Amiran Kâhin ona 'sakın bu rüyayı ve sırrı kimseye söyleme'; ‘senin kaç oğlun var?’ diye sordu. O, üç diye cevap verince Kâhin 'her üçü de padişah olacaklar' dedi. Bu ona inanılmaz geldi. O kadar fakir olmasına rağmen gitti elinde olan iki üç çadırını sattı, birkaç koyun alarak sadaka etti (Oğuz Kağan Destanı, 1982: 73; Ebu’l Gazi Bahadır Han, 1996: 77; Köprülü, 1991: 7-8). 
Yukarıdaki pasaj, bir halk destanından alınmış olması bakımından diğerlerine kıyasla daha fazla öneme haizdir. Her ne kadar destanın 15. asırda yazıya geçirildiği bilinse de bundan çok önceki dönemlerde halk ağzında sözlü olarak yaşadığı malumdur (Bayat, 2016: 375-376). Hikâyenin Oğuznâme'de yer alan varyantının yukarıda verilen diğer tüm örneklerle örtüşen yanlarının bulunması ve rüyayı gördüğü belirtilen kişilerin Türk/Oğuz kimliği taşıması gibi detaylar da ayrıca mevzu bahis edilmelidir. Bu durum hikâyenin köken olarak Oğuzların sözlü hafızasından mülhem olduğunu, müteakip müelliflerin de kendilerinden önceki eserler kadar bu sözlü gelenekten istifade etmiş olabileceklerine işaret etmektedir. Dolayısıyla Oğuznâme içerisinde yer etmiş olan bu türden mitolojik anlatılar, halkın sözlü aktarımla yaşatılan hafızasının yansımalarıdır ve her çağın müellifi tarafından farklı sebeplerle kendi anlattığı dönem, zaman ya da devlete uydurulmuştur. ${ }^{4}$

Hikâyenin bütün versiyonlarını karşılaştıracak olursak, farklı dönemin müverrihlerinin kaleminde rüyayı gören öznelerin (Toksurmuş, Selçuk Bey, Sebüktegin, Osman Bey) değişmesi yanında yardımcı öznelerin de zamanın şartlarına uydurulduğu görülür. Nitekim Toksurmuş'un gördüğü rüya dönemin baskın Şamanist gelenekleri uyarınca bir kâhin (muhtemelen bir şaman) tarafından hayra yorulurken, Selçuklu Devleti'nin kurucusu Selçuk Bey ve Gaznelilerin kurucusu Sebüktegin'in gördüğü rüya bir muabbir (rüya yorumcusu) tarafından yorumlanmıştır. Doğal olarak Osmanlı dönemi müverrihleri özellikle Aşıkpaşazâde için ise bu yardımcı özne Osman Bey'in kürsüsü önünde oturduğu Şeyh Edebalı'dan daha uygun bir kişi olmazdı. ${ }^{5}$ Böylece Osman'ın, Edebalı'nın kızıyla evlendirilmesi meselesi de mantıksal ve meşru bir çerçeveye oturtulmuş olacak, daha da önemlisi İnalcık'ın altını çizdiği gibi (200ob: 138) Edebalı'nın Osmanlı hanedanını ve devletin kuruluşunda anahtar bir rol oynadığı vurgulanmış olacaktı. Anlatıda göbekten çıkan ağaç motifinin ana öge olduğunu düşünecek olursak diğerlerine kıyasla hikâyenin en çok özünden kopmuş şekli Hüseynî'nin Selçuk Bey hakkında anlattığı biçimidir. Bununla birlikte burada da netice (dünyayı gölgeleme, bir rüya yorumcusuna müracaat, soyunun dünyaya hâkim olması vs.) benzeşir ve bu anlatının da öz olarak diğerleriyle aynı mecradan beslendiğini gösterir.

Hikâyede yer alan ortak noktalara gelince, "göğsünden ağaç çıkma motifi" ile ilgili bütün kaynaklardaki değişik sürümleri karşılaştırdığımızda hepsinde ortak

\footnotetext{
4 M. Fuad Köprülü (1991: 8), bu tekrarların Osmanlı kaynaklarına yansıması hakkında iki ihtimal üzerinde durmuștur. Osmanlı kroniklerine halk ağzından geçmiş olma ihtimali veya Osmanlı sarayında çok önemsenen Reşidüddin'in eserinden doğrudan alınarak Osmanlı sülalesine uydurulma ihtimali. Halil ínalcık ise (2000a: 110) hem Anadolu Selçuklu sultanlarının hem de Türkmen beylerinin saraylarında tarih-hanlar (tarih okuyucuları) ve menakıbnâme okuyan halk şairlerinin mevcut olduğunu yazmakla bu dönemde yazılmış eserlere intikal eden sözlü belleğin kaynağına işaret etmektedir.

5 Bununla birlikte, Osmanlı tarihçileri arasında rüyayı bir muabbirin mi yoksa Edebalı'nın mı yorumladığı konusunda kararsız olanlar vardır. Her ikisinin ismini ananlar olduğu gibi (Anonim, 1992: 10; Oruç Beğ; 2008: 8) sadece muabbiri (Krş. Selâtin-nâme, 2001: 36) veya sadece Edebalı'yı ananlar (Aşıkpaşazâde, 2003: 58; Hoca Sadeddin, I, 1974: 28-29) vardır. Bu durum, yani her iki unsurun da geçiş dönemi kaynaklarında yer alması aslında önceki kaynaklardan alınan bilginin çağa uydurulması sürecinin doğal bir neticesiydi.
} 
bir husus dikkat çekmektedir: Bu hadisenin büyük devletlerin kuruluşu arifesinde gerçekleşmesi ve devletin kurucusunun bu onurlandırıcı rüyayı görmesi. Yeni kurulmuş bir devletin halk nezdinde kabul görmesi önemli bir aşamadır. Dolayısıyla sultanların manevi otoritelerinin kaynağını oluşturan bu tür efsanelerin yaygın hale gelmesi devletin varlığı için zorunluydu (Imber, 2000: 243244, 263). Bu noktada ilgili hanedan üyesine "meşruiyet kazandırma ve kutsallık atfetme" amacı güden müellifler için önceki devletlerin kuruluşu ile ilgili mukaddem kaynaklarda aktarılan yarı efsanevî hikâyeler eşsiz bir değer arz etmekteydi. Bahaeddin Ögel'in belirttiği gibi (I, 2010: 574) “yeni bir devlet kuran bir hükümdar, eski ve büyük bir devletin varisi imiş gibi hareket eder. Bütün sülaleler, kendilerini bir önceki sülaleye dayamak isterler. Bu suretle de saltanatlarını, halk gözünde meşru göstermiş olurlar" Gerçekten hikâyenin bütün versiyonlarında kurucu hükümdar pozisyonunda bulunan Toksurmuş, Sebüktegin, Selçuk Bey ve Osman Bey cihangir devletlerini kurmadan evvel gördükleri bu rüya ile sevinmişler, hatta esasen sıradan bir adam olan Toksurmuş, böyle onurlandırıcı bir rüya gördüğü için elindeki iki üç çadırı satarak birkaç koyun sadaka etmiştir. Ayrıca hikâyeyi yorumlaması için müracaat ettiği kâhin de hiçbir şekilde kimseye bu rüyayı anlatmaması noktasında onu uyarıyordu.

Devletlerin kuruluş aşamasında sıkça başvurulan buna benzer bir anlatı yine hanedanlara meşruiyet ve kutsallık atfetme aracı olarak yaygın şekilde kullanılmıştır. "Mushaf (Kur'an) önünde sabaha kadar bekleme” ve bu vesileyle ilgili hanedanın kökenine bir kutsiyet iliştirme. Bu tür rivayetlerin kökenleriyle ilgili değerlendirmede bulunmadan evvel anlatının 16. yüzyılda aldığı şekli görmek için bu asrın Osmanlı tarihçisi Neşrî’ye yeniden kulak verelim:

\begin{abstract}
Rivayet olunur ki ittifak [Ertuğrul] bir gece bir köyde köy imamının evinde konuk oldu. Ardında bir pencere vardı. Onun üzerine Mushaf (Kur’an) koymuşlardı. Hâne sahibi Ertuğrul'a dedi ki: 'Küstahlık olmasın, kereminden eğil, ardında nesne var alayım' Ertuğrul dedi: 'Ne nesne var?' Hane sahibi dedi ki: 'Peygamberimiz Muhammed Resulullah ahir zaman peygamberine inen Kelamu'llah var' Ertuğrul ev sahibi uykuya varınca gusledip abdest aldı ve Mushaf'tan yana dönerek huşu ve tevazu ile sabaha kadar el bağlayıp durdu. Ev sahibi uyanarak halimden haberdar olmasın diyerek yattı ve gözüne uyku geldi. Rüya âleminde Hak Teala celle ve ala tarafından "sen benim kelamıma hürmet ve ta'zim izzet-i ikram ettiğin için Ben de seni ve evladını ve sana tabi olanları âlemde ebedi muazzez ve mükerrem ve mübeccel ve muhterem kıldım (Neșrî, 2008: 37; Giese, 2000: 153; Imber, 2000: 261-262). ${ }^{6}$
\end{abstract}

Neşrî’nin eserinin bazı nüshalarında bu hikâyenin kahramanı yukarıda anlatıldığı gibi Ertuğrul iken aynı eserin diğer bazı nüshalarında Osman Gazi'dir (Neşrî, 2008: 37, not 442; Gibbons, 1998: 19-20; Giese, 2000: 154; Kafadar, 2010: 46). Tek başına bu durum dahi aynı olayı farklı öznelere uyarlama arzusunun bazı tarihçilerde (ve müstensihlerde) ne derece baskın olduğunu göstermektedir. Kuşkusuz bu uyarlamayı yaparken onların beslendiği bir mecra olması gerekiyordu. Bu noktada önceki tarihçilerin eserleri onlar için eşsiz bir ilham ve iktibas kaynağı olacaktı. Nitekim hikâye, Neşrî ile çağdaş olan Kemal adlı müellifin

\footnotetext{
${ }^{6}$ Kitapta Osmanlı Türkçesine ait kelimelerin günümüz Türkçesindeki karşılıkları kullanılmıştır.
} 
Selatin-nâme'sinde manzum şekilde aktarılır, fakat burada olayın kahramanı Ertuğrul değil Osman'dır:

[... ] Girü bir gün gelüben kondı mihman / Begâyet alimdi ehl-i Kur’an

Bilesünde anun var idi Mushaf / Anunla olurdı hem müşerref

Tilavet ederken hoca iy can / Temaşa etmeğe gelmişdi Osman

Tamam edüp kapadı [ol] mushafın / [vü] kisesine koyup sürdi yüzü

Didi hoca nedür bu kîse-vârı / Ki var durur katında itibarı

Didi kim budur Allah'un kelamı / Kilidi cennetün insün imamı

Bunun emrüledür dünyanun işi / Bununla kurtılır 'ukbide kişi

Bunun hükmile durur alınan can / Bununla kurtılur bu insile can

iç̧i tolu durur Allah'un adı / Bunu Osman işidip oldı şâdî

Didi pes niçün itmedün haberdar / Beni bu sırdan ey dânâ-yı esrar

$[\ldots]$

Dönüp ordan eve geldi Osman / Buyurdı kıldı ni'metler firavan

[...]

Yirinden [dahı] durdı ol melek-hu / Örü turdı Kelamu'llah’a karşı

Tazarru iyleyüp itdü münacât / Diledi ol Hüda'dan dürlü hâcât

[...] (Krş. Selatin-nâme, 2001: 38-39).

Görüldüğü gibi burada da hikâye, ufak farklarla aynı içeriğe sahiptir. Osmanlı öncesi İslam kaynakları araştırıldığında yukarıda anlatılan "göğsünden ay çıkma hadisesi” gibi bu anlatının da Osmanlı çağını aşarak Selçuklu dönemini anlatan bazı eserlerde Selçukluların atası için anlatıldığı görülmektedir. Nitekim bir 14. yüzyıl Selçuknâme'sinin anonim müellifi, hikâyenin benzerini Selçukluların kuruluş arifesi için anlatır:

[Lokman]7 o günlerde Müslümanlardan iyi ahlaklı bir kızı nikâhla kendisine aldı. Evvel vakitte töre şöyleydi. Cihazla birlikte yedi Mushaf [Kur'an] da beraber verilirdi. Zifaf gecesinde Lokman helali olan bu kadınla birleşmek istediğinde rahleleriyle yedi Mushaf'ı gördü. Karısına dedi ki ‘biz bașka odaya gidelim burada Mushaf vardır'. Fakat başka kimseler dediler ki 'siz burada kalın biz Mushaf'ı başka bir yere götürelim'. Lokman cevap olarak 'yakışık alan bizim başka bir odaya gitmemizdir, bu Mushaf'ın burada kalmasıdır' dedi. Tanrı kelamına çok tazim ve saygı gösterdi. Başka bir odaya gitti ve orada zifaf yaptı. O gece Lokman, Muhammed (s.a) rüyasında gördü. Peygamber Efendimiz 'Aziz ol Lokman sen ki Mushaf' ı bu kadar aziz tuttun dünyada ve ahirette sen ve senin çocukların aziz olsunlar' buyurdu. Peygamberin etrafında bulunan kimseler de bu duaya âmin dediler (Anonim, 1952: 2; Köprülü, 1991: 8; Turan, 1998: 66).

Görüldüğü gibi bu metin, öz itibariyle yukarıda Osmanlıların atası Ertuğrul ve Osman için anlatılanla aynı içeriğe sahiptir. Her ikisi de bir büyük

\footnotetext{
7 Bazı Selçuknâmelerde Selçukluların atası Dukak'ın adı Lokman şeklinde kaydedilir (Bkz. Ravendî, I, 1999: 86; Nişaburî, 2018: 76; Anonim, 1952: 3; Reşidüddin, 2011: 70).
} 
imparatorluğun (Selçuklu/Osmanlı) doğuşu öncesinde bu hanedanların üst atası (Dukak/Ertuğrul veya Osman) için aktarılmış ve böylece onlara bir kutsiyet atfedilmiştir. Çağdaş yazar Osman Turan'ın dediği gibi (1998: 65), Dukak Bey’in Müslüman olmadığı net bir şekilde bilindiğine göre bu rivayetin Selçuklular için anlatılan kısmı, bu hanedanı kutsîleştirmek ve onun Müslüman olmayan ilk ceddinin de dinî hamiyetini göstermek kaygısıyla eklenmiş olmalıdır. Aynı meşruiyet kaygısı, hikâyeyi Osmanlı devleti kurucularına uyduranlar için de söz konusu olduğu halde efsane ve taklitten beslenen bu tür derleme metinlerin günümüz tarihçilerini bile yanılttığı görülmektedir. Mesela H. A. Gibbons (1998: 21-23), yukarıda bahsedilen menkıbevî anlatıya dayanarak ilk Osmanlıların Söğüt'e geldikleri sırada müşrik oldukları nazariyesini uydurmuştur. Oysaki M. Fuad Köprülü’nün de dikkat çektiği gibi (1991: 7), hikâyenin Osmanlı için anlatılan versiyonu “Osmanlı sülalesine Anadolu'daki diğer Türk kabileleri üzerinde hegemonyasını kurmak için ilahî bir meşruiyet kazandırma” düşüncesiyle dönemin tarihçileri tarafından bu hanedanın tarihine eklemlenmişti. Aynı fikirde olan F. Giese (2000: 154) ise konuyu değerlendirdiği bir makalesinde şöyle yazmaktadır: “(...) Ben bunlarda İslamiyet'in kabulünü değil, basit koşullarda oluşmuş Osmanlı hanedanının Anadolu'nun diğer Türk kabileleri üzerinde egemenlik kurabilmesi için Osmanlı hanedanına Tanrısal bir meşruiyet kazandırma çabasını görüyorum" Bir hanedana meşruiyet kazandırma ve kutsiyet atfetme dışında, Orta Çağ müelliflerinin eserlerini ilginç kılma kaygısıyla bu nevi hikâyeleri zamana ve duruma uydurmak alışkanlığı da bu türden tekrarların bir "topos" haline gelerek birçok kaynakta farklı öznelerle boy göstermesinin sebebini izah etmektedir. Esasen yukarıda verdiğimiz "göğsünden ay çıkma" ile "Mushaf'a saygı" hadiselerinin Selçuklu kuruluşu için de anlatılmış olması, Osmanlı kronik yazarlarının kendi eserlerini yazmadan evvel Selçuklu dönemi kroniklerini ne kadar iyi tahlil ettiklerini göstermektedir.

Orta Çağ tarihçilerinin tekrar tutkusuna vereceğimiz bir diğer örnek "okluğundan ok çıkarıp kırma” hadisesi hakkındadır. Kaynaklarda farklı öznelerle anlatılan bu hikâyecik de bir devletin kurucularının bir arada ve iş birliği içinde olduğunu göstermek, bu vesileyle onlara meşruiyet atfetme bağlamında hem Selçuklular hem de Moğollar için kullanılmıştır. Ravendî'nin (ö. 1207'den sonra) Selçuknâme'sinde Selçukluların kurucusu Tuğrul Bey hakkında anlatılan sürümü şöyledir:

Tuğrul Bey kardeşine [Çağrı] bir ok verdi ve dedi: 'Kır' O, onun arzu ettiği gibi onu parçaladı. Tuğrul Bey iki oku bir araya getirdi, aynı şeyi yaptı. (Bunun üzerine) üç tane verdi, güçlükle kırdı. Oklar dört olunca kırmak imkânsız oldu. Tuğrul Bey dedi ki: ‘Biz de tıpkı bu oklara benzeriz. Ayrı ayrı olduğumuz müddetçe biraz kuvvetli olan herkes bizi kırmağa yenmeğe kasteder; fakat bir arada olursak kimse bizi yenemez. Eğer aramızda anlaşmazlık çıkarsa dünya ele geçirilemez, düşmanlarımız galip olur ve hükümdarlık elden gider (Ravendî, I, 1999: 101; Köymen, 1976: 17).

Tarihçinin, anlattığı devlete veya hanedana olan hayranlığı veya o hanedan mensuplarından nemalanma ülküsü bu tür hikâyelerin kendi zamanına uydurulmasında başat bir etken olmuş olabilir. Nitekim İlhanlı dönemi tarihçisi 
Ata Melik Cüveynî (ö. 1283), Tarih-i Cihangûşa adlı eserinde bu anekdotu olduğu gibi Cengiz Han'a ve Moğollara uyarlamaktan imtina etmemiştir:

[Cengiz Han] oğullarını bir araya getirerek onlara şöyle nasihatte bulundu. Okluğundan bir ok çıkararak kırdı. Sonra okların sayısını ikiye çıkararak onları da kırdı. Bu şekilde okların sayısını birer birer arttırdı. Sayı çoğalıp el gücüyle kırılamayacak duruma gelince oğullarına dönerek bu hikâye sizinle ilgilidir. Eğer ince bir oka ilaveler yapılırsa güç kazanır, rakipler onu kıramaz. O halde siz kardeşler arasında yardımlaşma ve dayanışma sağlanırsa başkaları ne kadar güçlü olsalar sizi yenemezler (Cüveynî, 2013: 94). ${ }^{8}$

Aslında bu anlatının da Türk/Oğuz halklarının sözlü hafızasından beslendiğini iddia etmek için geçerli sebeplerimiz mevcuttur. Her şeyden önce bazı çağdaş kaynaklarda hikâyenin Oğuz Kağan ile ilgili bir versiyonu olduğu belirtilir (Turan, 1998: 107). Bu bilgi doğruysa Oğuzlar arasında sözlü gelenek olarak yaygın bir şekilde yaşatıldığı ve bu vesileyle Orta Çağ kaynaklarına aktarıldığı söylenebilir. Dahası, Türklerin ilk yazılı eserleri olarak kabul edilen ve 8 . yüzyıla tarihlenen Orhun abidelerinde buna çok benzeyen bir ifade geçmektedir. "(Bir şeyi) yufka iken toplaması (=bükmesi) kolay imiş, ince iken kırması gene kolay; fakat yufka kalın olur ise bükmesi zorlu imiş; ince kalın olursa parçalanması zorlu imiş" (Orkun, 1994: 104). Bu pasaj, Türkler arasında birlik ve beraberliğin önemini vurgulamak için bu darbımeselin sürekli anlatıldığını ve zamanla yazılı hale geçerek bozkır kavimleri anlatan Orta Çağ kaynaklarında kalıplaşmış bir söylem haline geldiğine işaret etmektedir.

Bozkır kavimlerinden söz etmişken, Türklerle Moğollar arasında sürekli yer değiștiren bir diğer onurlandırıcı anlatıdan daha bahsedelim. Yukarıda verilen örneklerde tarihçinin anlattığı kavim, hanedan ya da devlete meşruiyet kazandırma kaygısından ve bu amaçla müelliflerin bilgiyi değiştirme ya da kendi zamanına uyarlamaktan çekinmediğinden söz etmiştik. Kaşgarlı Mahmud, lügatinde Türk sözcüğünü açıklarken şöyle bir hadis-i şerife yer verir: "Yüce Tanrı 'Benim bir ordum vardır, ona Türk adı verdim, onları doğuda yerleştirdim. Bir ulusa kızarsam Türkleri o ulus üzerine musallat kılarım. İşte bu Türkler için bütün insanlara karşı bir üstünlüktür” (Kaşgarlı Mahmud, I, 1985: 351). Bu ifade, Selçuklu Türklerinin İslam dünyasında mutlak üstün oldukları bir zamanda (1074'te) yazıldığı bilinen Divanü Lugati't-Türk adlı eserde geçmektedir. Birkaç asır sonra aynı coğrafyada Moğolların egemen hale geldikleri bir zamanda benzer ifadeler bu kez Moğollar için dönemin tarihçilerinin eserlerine yansımıştır. Bunlardan Cüveynî, Tarih-i Cihanguşa adlı eserinin girişinde Cengiz Han ve Moğolları tanıtıp övdükten sonra onlar hakkındaki iddialarına dini bir meşruiyet kazandırmak için şöyle der: "Onlar [Moğollar] benim atlılarımdır. Bana isyan edenlere onlarla intikam alırım" kudsi hadisinin Cengiz Han ve atlıları için söylendiğine hiç şüphe yoktur" (Cüveynî, 2013: 85). Aynı şekilde Moğolların baskın egemenlik çağında Anadolu'da yaşayan bir diğer müellif Aksarayî'nin eserinde de bu kalıplaşmış

\footnotetext{
${ }^{8}$ Cüveynî ile çağdaş bir Selçuknâme yazarının eserinde bir olay vesilesiyle geçen "oklar bir araya getirilirse sağlamlık kazanır; onları ayırdıkları zaman birer birer kırıır" şeklindeki şiir dönemin birçok tarihçisinin beslendiği mecranın aynı olduğunu göstermesi bakımından ilginçtir (Aksarayî, 2000: 139).
} 
ifadenin farklı bir versiyonu geçer. Müellifin yazdığına göre Moğol hanı, azılı düşmanları Memlük hükümdarına gönderdiği mektupta şu ifadeyi kullanmıştır: “[...] Şam büyükleriyle ordu başbuğları [Memlükler] bilmelidirler ki biz Allah'ın ordusuyuz. Bizi kendi öfkesinden yaratmış, kahretmek istediği uluslar üzerine saldırtmıştır" (Aksarayî, 2000: 146. Ayrıca bk. Eflakî, I, 1973: 114).

Görüldüğü üzere ifadeler arasındaki benzerlik hissedilecek derecede belirgindir. Yazan müelliflerin hayatını karşılaştırdığımızda onların bilgiyi isnat ettikleri kavmin güçlü olduğu zamanda yaşamış olması bir tesadüf olarak görülmemelidir. Aslında bu anlatının da İslam öncesi dönemden beslendiğini ve İslam sonrası dönemde çağın şartları ölçeğinde müellifler elinde kendi dönemine uydurulduğunu söyleyebiliriz. Bu çerçevede mesela Avrupa Hun hükümdarı Attila'nın (434-453) “Tanrı'nın kırbacı” olarak anılması veya “Allah'ın Avrupalıları ve Bizanslıları cezalandırmak için Hunları gönderdiği” gibi İslam öncesi döneme ait kaynaklarda geçen ifadeler bu anlatının kökenlerine ait izler olmalıdır. Bu tür söylemlerin bozkır halklar (Türk/Moğol) için yer değiştirip tekrarlanmış olması da meselenin odaklanılması gereken diğer bir boyutudur. Bu durum, Türkler arasında yaygın olan Şamanizm/Göktanrı inanç sistemlerinde “Tanrı'nın (Tengri) kendilerini koruduğu ve mümtaz kıldığına” dair düşüncenin İslam sonrası aldığı biçimdir ki Moğol hakimiyetinin başlamasıyla birlikte onlar için uyarlanmıştır (Turan, 2009: 194-195; Şeker, 2016: 36, not 53).

Orta Çağ müelliflerinin rağbet ettiği ve dönemin şartlarına uygun şekilde kendi eserlerine uyarladığı benzer tekrarlardan biri de "yanlış yere konan posta güvercini” hikâyesidir. Bununla ilgili rastladığımız ilk anlatı Anonim Haçlı Vekayinâmesi'nde 1124 yılında Haçlıların Sur şehrini kuşatması vesilesiyle aktarılır:

\begin{abstract}
1124 yılında Venedikli denen bazı Franklar büyük bir ordu topladılar. Birçok gemi donattılar ve Dukas adındaki bir kralın yönetiminde Kudüs'e gitmek üzere denize açıldılar. Sur ve Sidon kıyılarına gelip gemilerini karaya çektiler. [...] Sur hala Müslümanların elinde bulunduğundan ve Frankların aldığı yerlerden kaçanlar oraya sığınmış olduklarından orayı sardılar. Hem deniz ve hem de karadan saldırdılar. Her türlü silahla çarpıştılar. [...] kuşatma yedi ay sürdü. Duvarlarda gedikler açıldı, bazı duvarlar yıkıldı ama garnizon dayanmaya devam etti. Yiyecek azaldığı vakit sıkıntıya girdiler. Mısırlı efendileri onlara umut vermedi. O vakit Şam valisine dönüp oraya bağlanmak üzere yardım istediler. Kimsenin içeri girip çıkmasının olanağı yoktu. Bundan dolayı iletişimi güvercinle kuruyorlardı. Şam valisi büyük bir ordu topladı ve güvercinle şu bildiriyi gönderdi. 'Belirli bir günde sizi kurtarmaya büyük bir orduyla geleceğim, güçlü olun kahramanca dayanın, gevşemeyin'. Tanrı'nın isteğiyle güvercin Frank kampına düştü, bildiriyi okuyup tersini yazdılar. 'Yardımınıza gelmemizi yazdınız ama gelemiyoruz. Elimizde asker yok. Kenti yaşamınızı güvenceye alarak teslim edin' Bunu güvercinle bağlayıp bıraktılar. Yiyecekleri olmadığından Surlular umutlarını kaybettiler (Anonim Süryani, 2005: 36-37).
\end{abstract}

Dönemin şartlarında posta güvercini ile haberleşmenin yaygınlığı düşünüldüğünde bu olmayacak bir hadise değildir. Bütün giriş çıkışları tutulmak suretiyle kuşatılmış bir kaleden bir güvercin aracılığıyla yardım istenebilir, bu güvercin bir şekilde düșman otağına düşebilir ve düşman da bu fırsattan kendi çıkarları istikametinde istifade edebilir. Ancak hadisenin neredeyse aynı haliyle 
farklı zamanlarda farklı özneler için anlatılması bunun çoğu zaman müellifin eserinde merkeze aldığı unsuru (din, kişi, devlet, halk vs.) ön plana çıkarmak veya eserini bu nevi hikâyelerle ilginç kılmak için yaptığı bir uyarlama olduğuna işaret etmektedir. Nitekim yukarıda anlatılan hadise neredeyse ayn motiflerle sadece üç yıl sonra (1127'de) gerçekleșen Zengi'nin Nusaybin kuşatması vesilesiyle ỉbnu'l Esir (ö. 1233) ve İbn Vâsıl'ın (ö. 1298) vekayinâmelerinde hayret dolu cümlelerle anlatılır. İbnu'l Esir'deki varyant şöyledir:

[...] İmâdeddin [Zengi], daha sonra Cezîre'den Nusaybin'e gitti. Burası Mardin hâkimi Hüsameddin Temürtaş'ın elindeydi. İmâdeddin şehrin önüne karargâh kurunca Hüsameddin Hısn-ı Keyfâ hâkimi amcazadesi Rüknüddevle Dâvud b. Sökmen b. Artuk'un yanına gidip Atabeg Zengî'ye karşı yardım istedi, o da bizzat yardıma geleceğini vaat etti ve askerlerini topladı. Temürtaş daha sonra Mardin'e döndü ve posta güvercinlerinin kanadına mektuplar bağlayıp Nusaybin'e gönderdi, oradaki askerlere kendisinin ve amcazadesinin büyük bir orduyla gelip İmâdeddin'i oradan uzaklaştıracaklarını bildirdi, bunun için de şehri beş gün müddetle muhafaza etmelerini istedi. Atabeg Zengî çadııında bulunduğu bir sırada karşısındaki çadıra bir kuş düştü. Emir verip kuşu avlattı ve kanadında bir mektup buldu. Okuyup içindekilere vakıf olduktan sonra başka bir mektup yazılmasını emretti. Bu mektupta: 'Amcazadem Rüknüddevle'nin yanına gitti, o bana yardım ve asker göndermeyi vaat etti. Onun gelmesi yirmi günü geçebilir' diyor ve şehri o gelinceye kadar muhasara etmelerini emrediyordu. İmâdeddin daha sonra bu mektubu posta güverciniyle gönderdi. Güvercin, Nusaybin'e girdi. Nusaybin'dekiler mektubu okuyunca ne yapacaklarını şaşırdılar. Şehri bu kadar uzun bir süre muhafaza edemeyeceklerini biliyorlardı. Hemen Atabeg Zengî'ye haber gönderip onunla barış yaptılar ve Nusaybin'i ona teslim ettiler, böylece Temürtaş ile Davud'un planları suya düştü. Bu garip bir hadiseydi (ibnu'l Esir, X, 1991: 510-511; ibn Vâsıl, I, 1957: 35-36). ${ }^{9}$

$\mathrm{Bu}$ tür rastlantısal olaylar eseri ilginç kılacağı ve daha okunur hale getireceği için müelliflerin devamlı itibar ettiği türden hikâyeler olmuştur. Nitekim hem İbnu'l Esir hem de İbn Vâsıl hikâyeyi aktardıktan sonra "bu ilginç bir olaydı" diyerek cümlelerini bitirirler. Müellifinin bir din adamı olduğunu bildiğimiz Haçlı Vekayinâmesi'nde yer alan sürümünde ise hadiseye dini bir motif yüklenir ve güvercinin “Tanrı'nın isteğiyle” Frank kampına düştüğü belirtilir.

Orta Çağ müelliflerinin kendi zamanlarına uydurup eserlerine aktardıkları bir diğer konu, vezirlerin mal varlığı ve haşmetinin onların ölümüne sebep olduğu ile ilgili klasik anlatıdır. Bu dönem müelliflerinin kaleminde vezirlerin/ümeranın sultanlarla boy ölçüşecek kadar mal varlığı edinmesi ve bu vesileyle düşman addedilmeleri meselesi her zaman ilgi çeken konulardan biri olmayı başarmıştır. Farklı dönemde farklı devlet veya kişiler için anlatılan versiyonu çeșitli müelliflerin eserlerini süslemektedir. Kronolojik sırayla anlatacak olursak ilk rastladığımız Nizamülmülk (ö. 1092) ile alakalı olandır. Bir Selçuknâme'de onun mal varlığının sultan Melikşah (1072-1092) ile yarışacak düzeyde olduğu dedikoduları yayıldığında sultanın buna hayli içerlediği yazııı:

Tâcülmülk'ün, Nizâmülmülk hakkındaki iftiralarından biri de şu idi: ‘Nizâmülmülk her yıl fakihlere sufilere karilere üç yüz bin dinar para veriyor, eğer bu para ile bir ordu teçhiz

\footnotetext{
9 Bu tür olayların Orta Çağ ve Batı kaynaklarından sık sık tekrarlanan bir anlatı olduğu hakkında (Demirkent, II, 1994: 86 , not 353).
} 
edilirse onunla İstanbul surlarını bile fethetmek mümkündür' dedi. Sultan [Melikşah] bunu işittiği vakitte Nizamülmülk'ü yanına çağırdı ve bu mesele hakkında ona sordu (Hüseynî, 1999: 46).

Yukarıda Nizâmülmülk için verilen örnek Selçuknâme müellifi İbn Bibî’nin (ö. 1285'ten sonra) kaleminde Anadolu Selçuklu emirlerinden Seyfeddin Ayaba'nın katli için daha bariz bir gerekçe olarak karşımıza çıkmaktadır:

\begin{abstract}
Sultanın [Alaaddin Keykubad] mutfağında saray görevlileri ve diğerleri için 30 baş kurban kesilirken Emir Seyfeddin Ay-aba'nın mutfağında 80 baş koyun kesilirdi. O, işlerin çekip çevrilmesi konusunda bütün yetkileri elinde bulundururdu. Sultanın huzurundan ayrılıp evine gittiği zaman ondan izinsiz padişah sarayına kimse yaklaşamazdı. Diğer devlet emirleri de onu kendilerinin başkanları veya büyükleri olarak görürlerdi. Önemli işlerde onun görüşünü alırlar ona göre davranırlardı. Onun emrine sultanın kapı bekçisinin karşı gelmesi mümkün değildi. O, Sultanın saltanat tahtına oturuşundan beri bu yolu izlemiş ve bu huyundan hiç vazgeçmemişti. Onun bu davranışları yüzünden sultanın kalbinde kin ve nefret yer etmişti (ibn Bibî, 2014: 287; Yinanç, I, 1944: 86).
\end{abstract}

Farklı zamanlarda kaleme alınmış bu hikâyeler, Orta Çağ tarihçilerinin bilgi tekrarlarına olan hevesini ve önceki dönem kaynaklarında gördüklerini kendi zamanlarına uydurma alışkanlığını göstermesi bakımından dikkate değer görünmektedir.

\title{
Benzer Ifadeler, Bariz Deformasyonlar
}

Orta Çağ tarih yazım üslubunda, bağlama göre zamanı ve öznesi değiştirilerek anlatılan aynı olaylar yanında bazı durumlarda bilginin özü/içeriği bozularak verildiği görülmüştür. Bunların da kısaca aktarılması Orta Çağ tarihçilerinin birbirlerini nasıl birer bilgi kaynağı gördüklerini, öncekilerden elde ettikleri bilgileri kendi zamanlarına uydurmak kaygısıyla nasıl değiştirdiklerini göstermek bakımından önem arz etmektedir. En eskilerden başlayarak Türklere yol gösteren kurt motifini ele alalım. Bu hadisenin Oğuz Destanı'nda geçtiği ve bozkır halklarının sözlü hafızasında önemli bir yer işgal ettiğini söylemeye gerek yoktur. Türk halkları arasında kurdun bir totem (ongun) olduğu bilinmektedir (bkz. Ögel, I, 2010: 13-21, 40-55) ve bu sebeple bu hayvanın Türk kavimlerine yol gösterme anlatısı -efsanevî olsa da- makul karşılanabilir. Esasen burada mevzubahis, mitolojik ögelerle inşa edilmiş olan bu hikâyenin uydurma olup olmadığı değil, hikâyedeki ana öznenin (kurt) farklı müelliflerin eserinde değişik hayvanlara inkılap etmesidir. Oğuz Kağan Destanı'nda şöyle anlatılır:

[...] [Oğuz Kağan] kırk gün sonra Muz Tağ adında bir dağın eteğine geldi. Çadırını kurdurdu ve sessizce uyudu. Tan ağarınca Oğuz Kağan'ın çadırına güneş gibi bir ışık girdi. O ışıktan gök tüylü ve gök yeleli büyük bir erkek kurt çıktı. Bu kurt Oğuz Kağan’a hitap etti ve: 'Ey Oğuz, sen Urum üzerine yürümek istiyorsun; ey Oğuz, ben senin önünde yürümek istiyorum' dedi. Ondan sonra Oğuz Kağan çadırını dürdürdü ve gitti. Gördü ki, askerin önünde gök tüylü ve gök yeleli büyük bir erkek kurt yürümektedir ve kurdun ardı sıra ordu gelmektedir. Gök tüylü ve gök yeleli bu büyük erkek kurt birkaç gün sonra durdu. Oğuz Kağan da askeri ile durdu. [...] Oğuz Kağan yine gök tüylü ve gök yeleli erkek kurdu gördü. O kurt, Oğuz Kağan'a: ‘şimdi, Oğuz, sen asker ile 
buradan yürüyerek, halkı ve beyleri götür; ben önden sana yol gösteririm' dedi. Tan ağarınca, Oğuz Kağan gördü ki, erkek kurt askerin önünde yürümektedir; sevindi ve ilerledi. [...] Yine bu gök tüylü ve gök yeleli erkek kurtla Hint, Tangut ve Suriye taraflarına yürüdü. Pek çok vuruşmadan ve pek çok çarpışmadan sonra onları aldı ve kendi yurduna kattı; onları yendi ve kendisine tabi kıldı (Bang-Rahmeti, 1936: 19, 23).

Oğuz destanında anlatılan bu hikâye, 12. asır Süryani müelliflerinden Mihail'in (ö. 1199) eserine de konu olmuştur. Mihail'de kurt efsanesi şöyle bir değişim geçirmiştir:

\begin{abstract}
Onlar [Türkler] şarktan garba geldikleri vakit, önlerinden giden kopeğe benzer bir hayvan görmüşlerdir. Bunun ne olduğunu ve nereden geldiğini bilmiyorlardı. Ona yaklaşamıyorlardı. Fakat yola çıkmak zamanı gelince, o, (yani hayvan) onları kendi dilleriyle çağırıp: "Kalkın” diyordu. Onlar, ayağa kalkarak, onu gittiği istikamete doğru takip ediyorlardı. Hayvan ne kadar yürüyorsa, kendileri de onun peşine gidiyorlardı. $O$, yolu değiştirince, kendileri de derhal o cihete doğru gidiyorlardı. $O$, durunca, orada karargâh kuruyorlardı (Süryani Mihail, 1944: 7; Turan, 1998: 113; Var, 2019: 72).
\end{abstract}

Oğuz Kağan Destanı'ndaki şeklini, orijin olarak kabul edersek bu metindeki deformasyon sadece kurdun bir köpeğe dönüşmüş olması değildir. Zaten müellif "köpeğe benzer bir hayvan" derken muhtemelen bir kurdu tarif ediyordu. Bu metindeki asıl bilgi-bozum Süryani müellifin metne fazladan kattıklarıdır. Mesela destanda kurdun tek muhatabı Oğuz Kağan olduğu halde burada tüm bir millete (Türkler) seslenmektedir.

Mihail'in bu bilgiyi edindiği kaynağın tam olarak ne olduğunu bilmek güzel olurdu. Kendisinin yakın ardılı olan bir diğer Süryani müellif Barhabreus (ö. 1286) bile bunları tebessümle okumuş ve kendi eserine şunları yazmaktan kendini alamamıştı: “Mübarek ihtiyar adamın [yani Mihail], güya bir köpeğin Selçuk oğullarına rehberlik ettiğine dair anlattığı hikâyeyi başka bir yerde göremedik, ihtimal ki kendisi bu hikâyeyi birinden işiterek yazdı yahut bizim görmediğimiz bir kitaptan nakletti. Çünkü biz bunu hiçbir kitapta görmedik" (Abu'l Farac, I, 1999: 293). Barhabreus'un metninde geçen “işiterek yazdı” ibaresinin altını çizmek gerekir. Çünkü bu ifade, yukarıda farklı olaylar hakkında dile getirdiğimiz sözlü bellek unsurlarının çağın kaynaklarına yansıması noktasında değerlidir. Aslında Mihail, eserinde bu hadiseyi anlatmadan birkaç satır önce Roma imparatoru Justinius (518-527) zamanında Türklere gönderilen Romalı elçilerden bahsediyor (Süryani Mihail, 1944: 7). Belki de Mihail, bilgiyi bu elçilerin kayıtlarından edinmiştir. Bu ihtimali destekleyici nitelikte bir veriye sahibiz. Esasen bir Roma bürokratı olan ve Gotların tarihiyle ilgili önemli bir eser kaleme almış olan 6. yüzyıl tarihçisi Jordanes (ö. 575 ?) yine Türklerle (Avrupa Hunları) ilgili bu hikayeyle örtüşen bir anekdot anlatır:

[...] Hunlar Gotların ülkesine geldiler. Nüfusları arttıktan sonra hile ve yağmacılıkla komşu kavimlerin dirliğini bozuyorlardı. Sadece avcılık yapıyorlar, başka işten anlamıyorlardı. Bu kavmin avcıları Maeotis'in [Azak Denizi] iç kısımlarında kıyıda avlanırken ansızın dişi bir geyik karşılarına çıktı ve bataklığa girip bazen ilerleyerek bazen de durarak onlara yol gösterici oldu. Dişi geyiği takip eden avcılar deniz gibi geçilemez olduğunu düşündükleri Mateois bataklı̆ını yürüyerek geçtiler. Kısa bir süre 
sonra bilmeyerek i̇skit ülkesine geldiler. O zaman dişi geyik ortadan kayboldu (Jordanes'ten aktaran Ahmetbeyoğlu, 2018: 29; Ögel, l, 2010: 578).

Mihail, eserinde anlattığı bilgiyi kimden almış olursa olsun, onun anlattıklarının hem Oğuz Kağan'ın gök yeleli kurt hikâyesinde hem de burada anlatılan dişi geyik efsanesiyle benzeştiği tartışılmazdır. Burada ilk olarak akla, halk ağzında kurt olarak anlatılan yol gösterici hayvanın Romalı yazarların elinde geyiğe evrilmiş olduğu gelebilir. Ancak bu ön kabul yanıltıcı olabilir. Çünkü Hunlar zamanından bu yana günümüze ulaşan dokumalarda oldukça yaygın şekilde kullanılan geyik figürlerinden yola çıkarak onlar arasında geyiğin de bir ongun olarak tahayyül edildiğini rahatlıkla söyleyebiliriz (Ögel, I, 2010: 24-25). ${ }^{10}$ iki hayvanı birbirine tercih etmek de yanıltıcı olabilir, çünkü her iki hayvanın da bozkır uluslarınca kutsal görüldüğü bilinmektedir. Nitekim Moğolların Gizli Tarihi adlı eserde Temuçin'in (Cengiz Han) ve ceddinin bir bozkurt ile beyaz bir dişi geyikten doğduğu yazılıdır (Anonim, 1986: 3, 279; Ögel, I, 2010: 43, 575). Gelinen nokta, bizleri yeniden sözlü hafızaya odaklanmaya sevk ediyor. Muhtemelen halk hafızasının değişik versiyonları, faklı dönemlerde yazılmış eserlere değişik sürümleriyle intikal etmiştir.

Bazı Orta Çağ tarihçilerinin elinde bariz bir deformasyona uğrayan bir diğer örnekten bahsedelim. Çehar Makale adlı eserin yazarı Nizam-ı Aruzî (ö. 1157 ?)'de Samanî emiri Nasr b. Ahmed'in (914-943) Buhara'ya dönmesi için dönemin meşhur şairi Rudekî (ö. 941) tarafından bir şiir okunduğu söylenir. Şiir şöyledir:

Ey Buhara! Sen şad ol ve çok yaşa/Padişah sana misafir geliyor.

Emir bir ay; Buhara ise gökyüzüdür/Ay gökyüzüne doğru geliyor.

Emir bir Servi Buhara ise bostandır/Servi de bostana doğru geliyor.

Nizami Aruzî’nin verdiği detaylara göre Herat'ta kışlayıp Buhara'ya dönmeyi unutan Nasr b. Ahmed bu muhteşem dörtlüğü duyduğunda o kadar etkilenir ki çizmesini bile giymeden atına biner ve şairin övdüğü Buhara'ya yönelir. Atının dizginini ayağının altına alır ve Buhara'ya varıncaya kadar hiç çekmez (Nizami Aruzî, 2016: 49-50). Birkaç asır sonra aynı şiir ve hikâye, müellif Cüzcanî'nin eserinde aynı şekliyle başka bir şaire mal edilerek Büyük Selçuklu sultanı Sancar (1117-1157) için anlatılır:

Ey Buhara! Mutlu ol ve çok yaşa/Şah sana misafir geliyor.

Şah aydır, Buhara gök/Ay göğe doğru geliyor.

Şah servidir, Buhara bahçe/ Servi bahçeye doğru geliyor.

Cüzcanî’ye göre, Merv'de kışlayıp kış geçtiği halde Buhara'ya dönmek gibi bir niyeti olmayan Selçuklu sultanı Sancar'ı ikna etmek isteyen devlet adamlarının, şair Muizzî’den (ö. 1124'ten sonra) Buhara'nın güzellikleri hakkında bir şiir okumasını talep etmeleri üzerine şair de yukarıdaki şiiri okumuştu. Bu

${ }^{10}$ Anadolu masallarında sıkça yer alan alageyik motifi ile erken dönem Osmanlı tarihlerine yansıyan Geyikli Baba (Aşıkpaşazâde, 2003: 566; Oruç Beğ, 2008: 17) gibi figürler de bu durumun yansımaları olmalıdır. 
kıtayı duyduğunda Sancar (aynen Nasr b. Ahmed gibi) yarı giyinik bir vaziyette dışarı çıkarak hızla atına binmiş, Buhara'ya gelip burada istirahat etmişti (Krş. Cüzcanî, 2015: 92).

Şiir sonrası anlatılan hikâyeyi karşılaştıralım: Şiirin esas sahibi olduğu diğer kaynaklarda verilen bilgilerle açıkça anlaşılan ${ }^{11}$ şair Rudekî, aslında Herat'a gidip Buhara'ya dönmek istemeyen Samanî hükümdarı Nasr b. Ahmed'i ikna etmek için bu şiiri okumuştu. Cüzcanî’nin, şair Muizzî’ye atfettiği sürümü ise -onun belirttiğine göre- Merv'de kalıp Buhara'ya dönmeyi unutan Sancar'ın ikna edilmeye çalışılması amacıyla söylenmiştir. İki şiir arasındaki mutlak benzerlik bir yana şiir sonrası Buhara'ya dönüş hikâyesi de birebir örtüşmektedir. Ancak birinci hikâyede Buhara'ya tercih edilen şehir Herat iken ikincide Merv olarak değiştirilmiştir. Kronolojik karşılaştırmalar yaptığımızda Cüzcanî’nin, şiiri ve dönüş hikâyesini Sancar dönemine uydurmak amacıyla hikâyenin zamanını, öznesini ve diğer bazı unsurlarını değiştirerek deforme ettiğine hükmedebiliriz.

İki farklı öznesi olan hikâyelerden biri de Diyojen'in Alp Arslan'a esir düştükten sonra akıbetine ilişkin sarf ettiği söylenen sözlerdir. 14. asır İlhanlı tarihçisi Reşidüddin Fazlullah (ö. 1318)'ın eserinde diyalog kısaca şöyledir:

[...] (Sultan) bu şekilde onu [R. Diyojen] birkaç gün meclisinde hazır bulundurdu. Bir gün Kayser sarhoş halde iken üzgün ve yorgun bir şekilde Sultan'a: 'Eğer padişah isen bağışla; kasap isen öldür; tüccar (bazargan) isen sat' dedi. Sultan onun kulağına iki küpe (halka) takıp canını bağışladı (eman) ve 'Gönül hoșluğuyla kendi memleketine git' diye buyurdu (Reşidüddin Fazlullah, 2011: 117).

Aynı diyalogu başka bir esaret vesilesiyle bundan yaklaşık yarım asır önce kaleme alınmış bir Ermeni kaynakta farklı öznelerle okuyoruz. Müverrih Vardan (ö. 1271) Hasankale Savaşı'ndan sonra (1048) Selçukluların eline esir düşen Gürcü prensi Liparit'in Tuğrul Bey'in huzurundayken aralarında şöyle bir konuşmanın geçtiğini yazar:

[…] Bu esnada Liparit esir düşerek sultanın yanına götürüldü. Sultan onu Müslüman olmaya davet etti. Liparit, sultanın yüzünü gördükten sonra onun emrini ifa edeceğini söyledi. Fakat sultanın huzuruna çıktıktan sonra: 'Seni görmeye layık olduktan sonra emrini ifa etmeyeceğim ve ölümden korkmayacağım' dedi. Sultan: 'Ne istersiniz?' diye sorunca esir prens şu cevabı verdi: 'Eğer tacirsen beni sat, cellatsan beni öldür ve eğer padişah isen beni bedelimle serbest bırak' Sultan: 'Ben ne seni satın alacak tacir ne de senin celladın olmak isterim; ben bir padişahım. İstediğin yere gitmekte serbestsin' dedi ve onu serbest bıraktı (Müverrih Vardan, 2017:34).

Görüldüğü gibi her iki metinde olay ve diyaloglar aynı olduğu halde olayın tarihi ve kahramanları farklıdır. Reşidüddin'in rivayeti, 1071'de gerçekleşen bir olayın 14. yüzyılda kaleme alınmış biçimi iken Vardan'ın rivayeti, 1048 yılında geçekleșmiş bir hadisenin 13. yüzyılda kaleme alınmış bir sürümüdür. Düz mantık düşünülecek olursa Vardan daha önce yazmış olduğu için Reşidüddin'in olayı kendi dönemine uyarlayarak bilginin özünü deforme ettiği söylenebilir. Ancak

\footnotetext{
${ }^{11}$ Bahse konu şiirin Rudeki'ye; hikâyenin de Samanî emiri Ahmed b. Nasr’a ait olduğu 14. asır müellifi Hamdullah Müstevfî tarafından da teyit edilmektedir (Bkz. Hamdullah Müstevfî-yi Kazvinî, 2018: 305-306).
} 
Reşidüddin, bu bilgiyi Vardan'dan önceki yüzyıllara tarihlenen başka bir vekayinâmeden almış olma ihtimali de göz önünde bulundurulmalıdır. Dolayısıyla bu anekdotun orijinal öznelerinin hangisi olduğunu tespit etmek zordur.

\section{Sonuç}

Yukarıda verdiğimiz birbirinden mülhem bütün bu olay, durum ve diyalogları anlatmaktan maksat, hangisinin daha doğru/güvenilir olduğunu tespit etmekten ziyade, temel yazım üslubu iktibas üzerine kurulu olan ve önemli ölçüde taklitten beslenen Orta Çağ tarihçisinin bilgiye dokunuşunun özde nasıl bir tahrifata sebep olduğunu göstermeye çalışmaktır. Verilen örneklerdeki metinler arası farklılıklar göstermektedir ki eserlerin müellifleri, muhtelif sebeplerle bu bilgi-bozumun önemli bir parçası olmuşlardır. Bilginin özünde meydana ge(tiri)len bu tür tahribat bazen çağın muktedir hanedanını meşruiyet kazandırmak için yapılırken bazen de edebi kaygılarla veya eseri ilginç hale getirmek için yapılmıştır. Bütün bunlardan çıkarılması gereken sonuç, tabi ki kaynaklarda yazılan her şeyin uydurma olduğu değil, verilen bilgilerin mukayeseli ve mantıksal bağlama oturtulduktan sonra kullanmanın ne kadar önemli olduğudur. Bu noktada tarihçinin elindeki en önemli koz, hangi asırda yazılmış olursa olsun bilgiyi tenkidî metotla mukayese ederek değerlendirme yöntemidir. $\mathrm{Bu}$ usul, genel olarak bir yerde verilen bilginin diğer kaynak(lar)da ne şekilde geçtiğini, aradaki farklılıkların neden kaynaklanmış olabileceğine dair mantıksal düşünme metoduna dayanmaktadır.

\section{Kaynakça}

(1982). Oğuz Kağan Destanı (Reşüdüddin Oğuznâmesi), (Tercüme ve tahlil Z. Velidi Togan), İstanbul: Enderun Yayınları.

Ahmed b. Mahmud. (1977). Selçuk-nâme, (Haz. Erdoğan Merçil), c. I, İstanbul: Kervan Yayınları.

Ahmed Eflakî. (1973). Menâkibü'l Arifin, (Çev. Tahsin Yazııı), c. I, İstanbul: Hürriyet Yayınları.

Ahmetbeyoğlu, A. (2018). Avrupa Hunları, İstanbul: Yeditepe Yayınları.

Aksarayî. (2000). Musâmeratü’l Ahbar, (Çev. Mürsel Öztürk), Ankara: TTK Yayınları.

Anonim Süryani. (2005), I. ve II. Haçlı Seferleri Vekayinâmesi, Çev. Vedii illmen, , İstanbul: Yaba Yayınları.

Anonim. (1952). Selçuknâme, (Anadolu Selçukluları Devleti Tarihi III), (Neşr. ve Trc. F. Nafiz Uzluk), Ankara: Örnek Matbaası.

Anonim. (1986). Moğolların Gizli Tarihi, (Çev. Ahmet Temir), Ankara: TTK Yayınları.

Anonim. (1992). Tevârih-i Âl-i Osman, (Haz. Nihat Azamat), İstanbul: Marmara Üniversitesi Yayınları. 
Âşık Paşazade. (2003). Osmanoğulları'nın Tarihi, (Haz. Kemal Yavuz-M. A. Yekta Saraç), İstanbul: K Kitaplığı.

Bang, W.- Rahmeti, G. R. (1936). Oğuz Kağan Destanı, İstanbul: Burhaneddin Basımevi.

Bayat, F. (2016). "Oğuznâme", Diyanet İslam Ansiklopedisi, c. Ek-2, İstanbul: TDV Yayınları, ss. 375-376.

Cüveynî. (2013). Tarih-i Cihangüşa, (Çev. Mürsel Öztürk), Ankara: TTK Yayınları.

Cüzcanî. (2015). Tabakat-ı Nasırî, (Terc. Erkan Göksu), Ankara: TTK Yayınları.

Demirkent, I. (1994). Urfa Haçı Kontluğu Tarihi, c. II, Ankara: TTK Yayınları.

Divitçioğlu, S. (2015). Oğuz'dan Selçuklu'ya, İstanbul: Alfa Yayınları.

Duygu, Z. (2019). Süryanilerde Tarih Yazıcılı̆̆ı, Mardin: Artuklu Üniversitesi Yayınları.

Ebu'l Gazi Bahadır Han. (1996). Şecere-i Terakime, (Türkmenlerin Soykütüğü) (Haz. Z. Kargı Ölmez), Ankara: Simurg Yayınları.

Gibbons, H. A. (1998). Osmanlı İmparatorluğu'nun Kuruluşu, (Haz. Mustafa Everdi), Ankara: 21. Yüzyıl Yayınları.

Giese, F. (2000). “Osmanlı İmparatorluğu'nun Kuruluşu Meselesi” Söğüt'ten İstanbul'a (Osmanlı'nın Kuruluşu Üzerine Tartışmalar), (Derleyen: Oktay Özel-Mehmet Öz), Ankara: Imge Kitabevi, ss. 149-175.

Gregory Abu'l Farac (Bar Habraeus). (1999). Abu'l-Farac Tarihi, (Çev. Ö. Riza Doğrul), c. I, Ankara: TTK Yayınları.

Hamdullah Müstevfî-yi Kazvinî. (2018). Tarih-i Güzide, (Çev. Mürsel Öztürk), Ankara: TTK Yayınları.

Hoca Sadeddin Efendi. (1974). Tacü't Tevarih, (Sad. İsmet Parmaksızoğlu), c. I, İstanbul: Başbakanlık Kültür Müsteşarlığı Kültür Yayınları.

Hüseynî. (1999). Ahbarü'd Devleti's-Selçukiyye, (Çev. Necati Lugal), Ankara: TTK Yayınları.

Imber, C. (2000). "Osmanlı Hanedan Efsanesi”, Söğüt'ten İstanbul'a (Osmanlı'nın Kuruluşu Üzerine Tartışmalar), (Derleyen: Oktay Özel-Mehmet Öz), Ankara: Imge Kitabevi, ss. 243-270.

ỉbn Bibî. (2014). el-Evâmiru'l Alâ'iyye fi'l Umûri'l-Alâ'iyye, (Selçuknâme), (çev. Mürsel Öztürk), Ankara: TTK Yayınları.

İbn Haldun. (2007). Mukaddime, c. I, (Haz. Süleyman Uludağ), İstanbul: Dergâh Yayınları.

İbn Vâsıl. (1957). Müferricü’l Kurub fi Ahbar Ben-i Eyyub, (Cemaleddin Eş-Şeyyal), c. I, İskenderiye.

ỉbnu'l Esir. (1991). el-Kâmil fi't Tarih, c. X, (çev. A. Özaydın), İstanbul: Bahar Yayınları.

İnalcık, H. (2000a). "Osmanlı Tarihçiliğinin Doğuşu”, Söğüt'ten İstanbul'a (Osmanlı'nın Kuruluşu Üzerine Tartışmalar), (Derleyen: Oktay Özel-Mehmet Öz), Ankara: Imge Kitabevi, ss. 93-117.

İnalcık, H. (2000b). “Âşıkpaşazâde Tarihi Nasıl Okunmalı?", Söğüt'ten İstanbul'a (Osmanlı'nın Kuruluşu Üzerine Tartışmalar), (Derleyen: Oktay Özel-Mehmet Öz), Ankara: Imge Kitabevi, ss. 119-145. 
Kafadar, C. (2010). İki Cihan Âresinde, (Osmanlı Devleti’nin Kuruluşu), (Çev. Ceren Çıkın), Ankara: Birleşik Yayınları.

Kanar, M. (1996). “Firdevsî, Diyanet İslam Ansiklopedisi, c. 13, İstanbul: TDV Yayınları, ss. 125-127.

Kaşgarlı Mahmud. (1985). Divan-ı Lügati’t Türk Tercemesi, c. I, (Çev. Besim Atalay), Ankara: TDK Yayınları.

Kemal. (2001). Selâtin-nâme (1299-1490), (Haz. Necdet Öztürk), Ankara TTK Yayınları.

Köprülü, M. F. (1991). Osmanlı Devleti'nin Kuruluşu, Ankara: TTK Yayınları.

Köymen, M. A. (1976). Tuğrul Bey ve Zamanı, İstanbul: MEB Basımevi.

Mevlâna Mehmed Neşrî. (2008). Cihannüma [Osmanlı Tarihi (1288-1485)], (Haz.

N. Öztürk), İstanbul: Çamlıca Yayınları.

Müverrih Vardan. (2017). Türk Fetihleri Tarihi (889-1269), (Trc. H. D. Andreasyan), İstanbul: Post Yayınları.

Nizami Aruzî. (2016). Çehar Makale, (Çev. Esin Eren Soysal), İstanbul: Demavend Yayınları.

Orkun, H. N. (1994). Eski Türk Yazıtları, Ankara: TDK Yayınları.

Oruç Beğ. (2008). Oruç Beğ Tarihi (Osmanlı Tarihi 1288-1502), (Haz. Necdet Öztürk), İstanbul: Çamlıca Yayınları.

Ögel, B. (2010). Türk Mitolojisi, c. I, Ankara: TTK Yayınları.

Ravendî. (1999). Rahatus' Sudûr ve Ayet-üs-Sürûr, (Gönüllerin Rahatı ve Sevinç Alameti), c. I, (Çev. Ahmet Ateş), Ankara: TTK Yayınları.

Reşidüddin Fazlullah. (2011). Camiü’t Tevarih, (Selçuklu Devleti), (Çev. Erkan

Göksu), İstanbul: Selenge Yayınları 2011.

Süryani Mihail. (1944). Vekayinâme, (Türkçe çev. H. D. Andreasyan), (Basılmamış TTK Nüshası).

Şeker, M. F. (2016). İslamlaşma Sürecinde Türklerin İslam Tasavvuru, İstanbul: Dergah Yayınları.

Turan, O. (1998). Selçuklular Tarihi ve Türk-İslam Medeniyeti, İstanbul: Boğaziçi Yayınları.

Turan, O. (2009). Türk Cihan Hâkimiyeti Mefkûresi, İstanbul: Ötüken Yayınları.

Var, U. (2019). "Süryani Mikhail Kroniği'nde Eski Türk Dini ve Türklerin İslamiyet'e Geçiş Sebepleri”, Ortaçağ Araştırmaları Dergisi, c. 2, Sayı: 1, ss. 68-79.

Zahirüddin Nişaburî. (2018). Selçuknâme, (Çev. Ayşe Gül Fidan), İstanbul: Kopernik Yayınları. 